\title{
Thallium Myocardial Perfusion Imaging Stress Test
}

National Cancer Institute

\section{Source}

National Cancer Institute. Thallium Myocardial Perfusion Imaging Stress Test. NCI

Thesaurus. Code C38058.

A nuclear imag ing procedure, using the radionuclide Thallium, that shows whether the heart muscle is receiving adequate blood supply under stress and/or rest conditions. 